\title{
PEMBENTUKAN BANK SAMPAH DI KEBAYANAN-I DESA PURON KECAMATAN BULU KABUPATEN SUKOHARJO
}

\author{
Dwi Astuti, Johan Umri Muharram, Yesi Listiana \\ Program Studi Kesehatan Masyarakat \\ Fakultas Ilmu Kesehatan, Universitas Muhammadiyah Surakarta \\ Email :dwi.astuti@ums.ac.id
}

\begin{abstract}
ABSTRAK
Tujuan umum dari kegiatan ini adalah memberdayakan masyarakat di Dusun Kebayanan-I Desa Puron dalam menerapkan system pengelolaan sampah secara benar. Sedangkan tujuan khusunya adalah membentuk bank sampah yang nantinya diharapkan akan mengurangi beban polutan, menambah manfaat ekonomi, serta menciptakan lingkungan bersih. Pada akhirnya outcame yang dapat langsung dirasakan adalah berupa kesehatan dan peningkatan penghasilan. Sasaran pada kegiatan ini adalah warga masyarakat Dusun Kebayanan-I Desa Puron khususnya para kader maupun pemuda karang taruna yang nantinya akan aktif sebagai penggerak bank sampah yang akan terbentuk. Adapun metode yang diterapkan meliputi tahapan identifikasi permasalahan dengan melakukan survey lapangan, menyusun plan of action (PoA), sosialisasi/penyuluhan, pembentukan kepengurusan, dan pendampingan. Hasil dari kegiatan ini adalah terbentuknya struktur Organisasi Bank Sampah dengan nama "MALIMPA" (Masyarakat Peduli Sampah) di Kebayanan 1, Desa Puron. Pada awal pelaksanaan program terkumpul $6,9 \mathrm{~kg}$ dengan anggota 4 orang. Pelaksanaan kedua anggota bertambah 5 menjadi 9 orang dengan total sampah terkumpul $21 \mathrm{~kg}$.
\end{abstract}

\section{PENDAHULUAN}

Menurut profil kesehatan Indonesia tahun 2015, jumlah rumah sehat secara nasional sebesar $80 \%$. Sedangkan persentase tempat pembuangan sampah (anorganik) $80 \%$ jamban yang memenuhi syarat kesehatan sebanyak $80 \%$, air bersih $85 \%$, dan tempat-tempat umum sehat $80 \%$. Sedangkan rumah tangga Berperilaku Hidup Bersih dan Sehat (PHBS) sebesar 75\%.Oleh karena itu, tingkat pencapaian terhadap 16 indikator PHBS masih membutuhkan perhatian karena rendahnya capaian sangat mempengaruhi derajat kesehatan masyarakat (Depkes,2009).

Penanganan sampah, sampai saat ini masih menjadi agenda penting dalam pencapaian indikator PHBS. Permasalahan sampah jika tidak ditangani dengan serius akan menimbulkan dampak yang serius pula, dikarenakan setiap orang pada setiap harinya mempunyai peran sebagai penghasil sampah sementara lahan tempat pembuangan akhir sampah semakin terbatas. Oleh karena itu perlu diterapkan sistem pengelolaan sampah yang tepat.Data dari Unit Pelayanan Teknis Daerah (UPTD) Persampahan Dinas Pekerjaan Umum (DPU) Sukoharjo, tercatat pada tahun 2013, rata-rata sampah yang diambil dari 12 kecamatan hanya $340 \mathrm{~m}^{3} /$ hari. Sementara pada tahun 2014 naik menjadi 360 $\mathrm{m}^{3} /$ hari; tahun 2015 sudah mencapai $380 \mathrm{~m}^{3} /$ hari; dan tahun 2016 mencapai 400-410 $\mathrm{m}^{3} /$ hari (UPTD Persampahan DPU Sukoharjo, 2016).

Amanat dalam Undang-Undang Nomor 18 Tahun 2008 tentang Persampahan, dinyatakan bahwa pengelolaan sampah harus mengikutsertakan masyarakat atau disebut dengan pengelolaan sampah berbasis masyarakat. Masyarakat diharapkan mampu melakukan pengelolaan sampah rumah tangga secara kelompok. Hal ini termasuk juga dalam Peraturan Pemerintah Nomor 81 Tahun 2012 tentang Pengelolaan Sampah 
Rumah Tangga, jika pemanfaatan sampah diterapkan maka akan mengurangi beban polutan, menambah manfaat ekonomi, serta menciptakan lingkungan bersih. Pada akhirnya outcame yang dapat langsung dirasakan adalah berupa kesehatan dan penghasilan.

Berdasarkan hasil analisis situasi berupa survei ke Dusun Kebayanan-I Desa Puron diperoleh data bahwa untuk pembuangan sampah khususnya sampah anorganik terdapat sebanyak $108 \mathrm{KK}(58,1 \%)$ yang bermasalah; dengan sebaran sebanyak 34 KK $(18,3 \%)$ tidak mempunyai tempat sampah dan sebanyak 74KK (41,9 \%) sudah mempunyai tempat sampah tapi tidak memenuhisyarat pembuangan sampah. Hasil observasi terhadap $74 \mathrm{KK}$ yang memiliki tempat sampah, tetapi lubang sampah belum cukup menampung sampah rumah tangga keluarga yang bersangkutan, sehingga penanganan sampah dengan cara dibakar supaya tidak menjadi sarang nyamuk, lalat, dan tikus. Padahal di sisi lain, proses pembakaran sampah akan menimbulkan cemaran atau polusi udara.

Hasil penelitian dari Asteria dan Heru (2016), telah membuktikan bahwa dengan adanya bank sampah ternyata telah mendorong adanya capacity building bagi masyarakat dikarenakan tumbuhnya kemandirian serta keswadayaan masyarakat. Selain itu, masyarakat menjadi semakin sadar, dengan pengetahuan serta kemampuan yang dipunyai ternyata mampu memotivasi untuk berkomitmen aktif dalam mengelola lingkungan di komunitasnya.

Pembentukan bank sampah bagi masyarakat Desa Puron diharapkan dapat berperan dalam melatih kepedulian masyarakat terhadap pengelolaan lingkungan, sehingga diharapkan kualitas lingkungan dan derajat kesehatan masyarakat tetap terjamin di masa yang akan datang. Selain itu, dana yang terhimpun bisa dimanfaatkan untuk menambah pendapatan atau pun untuk pengembangan program-program lain di desa.
Permasalahan yang telah diuraikan di latar belakang berawal dari ketersediaan tempat pembuangan sampah yang belum memenuhi syarat. Ditambah lagi dengan belum adanya upaya untuk mengelola sampah dengan 3R (reduce, reuse, recycle) sementara produksi sampah setiap hari semakin meningkat. Masyarakat belum mengelola sampah dengan baik, sampah dibuang begitu saja, dibiarkan menumpuk lalu dibakar. Proses pembakaran sampah memang relatif mudah, tetapi tidak menyelesaikan masalah karena justru akan menambah kadar polutan di udara. Berdasarkan identifikasi masalah tersebut dibuat perumusan masalah bahwa perlu dilakukan upaya pengelolaan sampah yang mampu sekaligus menerapkan prinsip 3R yakni dengan membentuk Bank Sampah di Dusun Kebayanan I Desa Puron. Sementara itu, di dusun sebelah yakni Dusun Kebayanan II dan Kebayanan III sudah terbentuk bank sampah dan sudah mulai dijalankan. Jika nantinya sudah terbentuk bank sampah di Kebayanan I diharapkan akan lebih mudah mengoptimalkan keberadaan tiga bank sampah di Desa Puron secara bersama-sama.

\section{METODE PELAKSANAAN}

Dalam rangka menyelesaikan permasalahan mitra, ada 5 tahapan yang dilaksanakan. Kegiatan ini melibatkan masyarakat yang aktif sebagai kader maupun karangtaruna di Kebayanan I Desa Puron dengan memberikan penyuluhan dan pendampingan. Metode yang diterapkan meliputi langkah-langkah sebagai berikut:

1. Identifikasi permasalahan dengan melakukan survey lapangan

Pada tahap awal akan dilakukan analisis situasi dengan melakukan observasi kelapang berupa survey ke tiap rumah tangga sehingga akan diperoleh datadata pelengkap mengenai kondisi sosialekonomi masyarakat mitra, kondisi lingkungan, sampai dengan melakukan identifikasi kegiatan-kegiatan apa saja yang dibutuhkan oleh mitra. 
2. Menyusun rencana kegiatan atau plan of action (PoA)

Pada tahap ini akan dilakukan proses penjadwalan pelaksanaan kegiatan berdasarkan hasil kesepakatan dalam musyawarah bersama tokoh masyarakat termasuk kader maupun pemudapemudi karang taruna.

3. Penyuluhan kepada warga masyarakat

Kegiatan ini merupakan upaya sosialisasi tentang pentingnya proses pengelolaan sampah oleh warga, dimana kemanfaatan nantinya yang akan dirasakan oleh warga sendiri. Materi yang diangkat mengenai bagaimana pentingnya prinsip 3R diterapkan oleh setiap rumahtangga, serta apa dan bagaimana bank sampah.

4. Pembentukan kepengurusan bank sampah Tahap ini merupakan proses awal agar kegiatan bank sampah dapat dijalankan dana dan struktur penanggung-jawab beserta wewenangnya sehingga keberlanjutan bank sampah kedepannya lebih terjamin.

5. Pendampingan

Kegiatan ini merupakan wujud dari pelatihan awal bagaimana bank sampah ini berjalan dengan adanya pengawasan yang sifatnya sementara. Kedepannya justru warga masyarakat sendirilah yang akan berperan aktif dalam menjalankan seluruh kegiatan dalam bank sampah ini.

Setelah terbentuk struktur pengurus Bank Sampah di Dusun Kebayanan-I Desa Puron, maka diharapkan ada manfaat yang akan diperoleh yaitu:

\section{Manfaat Jangka Pendek}

Dalam jangka pendek diharapkan ada proses pengelolaan sampah yang tersistem dengan sudah terbentuknya pengurus dengan masih-masing wewenang serta tanggung-jawabnya.

2. Manfaat Jangka Panjang

Manfaat jangka panjang yang diharapkan adalah dengan keberadaan bank sampah ini: a. Menambah penghasilan warga. Dengan pengelolaan yang baik dana yang terkumpul dapat dimanfaatkan juga untuk pengembangan usaha bidang ekonomi bagi warga maupun rencana ke depan yang mempunyai keinginan untuk memanfaatkan dana sampah ini bias untuk membayar pajak bumi dan bangunan.

b. Menciptakan lingkungan yang sehat sehingga derajat kesehatan masyarakat pun bias meningkat karena warga dapat terhindar dari penyakit-penyakit akibat dari pengelolaan sampah yang tidak tepat.

\section{LUARAN YANG DICAPAI}

\section{Hasil Survei}

Berdasarkan Survei Masyarakat Desa (SMD) untuk melihat kondisi lingkungan sekitar yang telah dilakukan pada 186 Kepala Keluarga di Dusun Platar an Dusun Puron Desa Puron.

Tabel 1.Gambaran Pemanfaatan Pekarangan Rumah Responden

\begin{tabular}{lcc}
\hline \multicolumn{1}{c}{ Keberadaan } & Jumlah & Persentase (\%) \\
\hline Pekarangan & 120 & 64,5 \\
Dimanfaatkan & & \\
Pekarangan Tidak & 66 & 35,5 \\
$\begin{array}{l}\text { Dimanfaatkan } \\
\quad \text { Total }\end{array}$ & 186 & 100 \\
\hline
\end{tabular}

Berdasarkan Tabel 1, diperoleh hasil 120 KK memanfaatkan Pekarangan rumahnya dan $66 \mathrm{KK}$ tidak memanfaatkan pekarangannya.

Tabel 2. Gambaran Kondisi Pekarangan Rumah Responden

\begin{tabular}{lcc}
\multicolumn{3}{c}{ Responden } \\
\hline \multicolumn{1}{c}{ Keberadaan } & Jumlah & Persentase (\%) \\
\hline Pekarangan Bersih & 141 & 75,8 \\
Pekarangan Tidak & 45 & 24,2 \\
Bersih & 186 & 100 \\
$\quad$ Total & 186 \\
\hline
\end{tabular}


Berdasarkan Tabel 2, diperoleh hasil 141

KK Pekarangan rumahnya dalam keadaan bersih dan $45 \mathrm{KK}$ pekarangannya dalam kondisi tidak bersih.

Tabel 3. Gambaran Keadaan Bebas Lalat Pada Rumah Responden

\begin{tabular}{ccc}
\hline Keberadaan & Jumlah & Persentase (\%) \\
\hline Bebas Lalat & 118 & 63,4 \\
Tidak Bebas Lalat & 68 & 36,6 \\
Total & 186 & 100 \\
\hline
\end{tabular}

Berdasarkan Tabel 3, rumah responden yang bebas lalat ada $118 \mathrm{KK}$ dan yang tidak bebas lalat ada $68 \mathrm{KK}$.

Tabel 4. Gambaran Keadaan Bebas Jentik Pada Rumah Responden

\begin{tabular}{ccc}
\hline Keberadaan & Jumlah & Persentase (\%) \\
\hline Bebas Jentik & 121 & 65,1 \\
Tidak Bebas Jentik & 65 & 34,9 \\
Total & 186 & 100 \\
\hline
\end{tabular}

Berdasarkan Tabel 4, keadaan rumah responden yang bebas jentik ada $121 \mathrm{KK}$ dan yang tidak bebas jentik ada $65 \mathrm{KK}$.

Tabel 5. Ketersediaan Pembuangan Air Limbah di Rumah Responden

\begin{tabular}{lcc}
\hline \multicolumn{1}{c}{ Ketersediaan } & Jumlah & $\begin{array}{c}\text { Persentase } \\
(\mathbf{\%})\end{array}$ \\
\hline Ada, Memenuhi Syarat & 102 & 54,8 \\
Ada, Tidak Memenuhi & 61 & 32,8 \\
Syarat & 23 & 12,4 \\
Tidak Ada & 186 & 100 \\
\hline \multicolumn{1}{c}{ Total } & &
\end{tabular}

Berdasarkan Tabel 5, responden yang memiliki pembuangan air limbah di rumah dan memenuhi syarat ada $102 \mathrm{KK}$, responden yang memiliki pembuangan air limbah di rumah tetapi tidak memenuhi syarat ada 61 $\mathrm{KK}$, dan yang tidak memiliki pembuangan air limbah di rumah ada $23 \mathrm{KK}$.
Tabel 6. Tempat Pembuangan sampah (anorganik) Responden

\begin{tabular}{lcc}
\hline \multicolumn{1}{c}{ Ketersediaan } & Jumlah & $\begin{array}{c}\text { Persentase } \\
\mathbf{( \% )}\end{array}$ \\
\hline Ada, Memenuhi Syarat & 78 & 41,9 \\
Ada, Tidak Memenuhi & 74 & 39,8 \\
Syarat & 34 & 18,3 \\
Tidak Ada & 186 & 100 \\
\multicolumn{1}{c}{ Total } &
\end{tabular}

Berdasarkan Tabel 6, Responden yang memiliki tempat pembuangan sampah anorganik dan memenuhi syarat ada 78 KK, sedangkan yang memiliki tempat pembuangan sampah tetapi tidak memenuhi syarat ada $74 \mathrm{KK}$, dan yang tidak memiliki tempat pembuangan sampah ada $34 \mathrm{KK}$.

Tabel 7. Penyediaan Air Bersih Responden

\begin{tabular}{lcc}
\hline \multicolumn{1}{c}{ Ketersediaan } & Jumlah & $\begin{array}{c}\text { Persentase } \\
(\mathbf{\%})\end{array}$ \\
\hline Ada, Memenuhi Syarat & 158 & 84,9 \\
Ada, Tidak Memenuhi & 23 & 12,4 \\
Syarat & & \\
Tidak Ada & 5 & 2,7 \\
\multicolumn{1}{c}{ Total } & 186 & 100 \\
\hline
\end{tabular}

Data penyediaan air bersih disana yang memiliki dan memenuhi syarat ada $158 \mathrm{KK}$, kemudian ada $23 \mathrm{KK}$ yang memiliki dan tidak memenuhi syarat, dan sisanya $5 \mathrm{KK}$ tidak ada penyediaan air bersih. 


\section{PoA (Plan of Action)}

Tabel 9. Rencana Kegiatan Pembuangan sampah (anorganik)

\begin{tabular}{|c|c|c|}
\hline Masalah & Pembuangan sampah (anorganik) & Pengumpulan sampah \\
\hline Penyebab & $\begin{array}{l}\text { Perilaku warga yang masih membakar } \\
\text { sampah/limbah kegiatan manusia } \\
\text { (sampah anorganik) }\end{array}$ & $\begin{array}{l}\text { Perilaku warga yang masih membakar } \\
\text { sampah/limbah kegiatan manusia } \\
\text { (sampah anorganik). }\end{array}$ \\
\hline Program & Pembentukan Bank Sampah & Bank sampah "MALIMPA" \\
\hline Kegiatan & $\begin{array}{l}\text { Pembentukan struktur program Bank } \\
\text { Sampah pada tanggal } 5 \text { Februari } 2017 \\
\text { di Camp Puron } 1 \text { dengan melibatkan } \\
\text { karang taruna kebayanan } 1 .\end{array}$ & $\begin{array}{l}\text {-Tanggal } 12 \text { Februari } 2017 \text { sosialisasi } \\
\text { di masjid AL-IKHLAS mengenai bank } \\
\text { sampah bersama ibu-ibu pengajian } \\
\text { Salimah }\end{array}$ \\
\hline Tujuan & $\begin{array}{l}\text { Menggerakkan ibuk-ibuk untuk } \\
\text { memanfaatkan sampah menjadi nilai } \\
\text { ekonomis }\end{array}$ & $\begin{array}{l}\text { Memberdayakan untuk memanfaatkan } \\
\text { sampah menjadi nilai ekonomis } \\
\text { sehingga tidak menumpuk dan tidak } \\
\text { menyebabkan sumber penyakit. } \\
\text { Menggerakkan karang taruna }\end{array}$ \\
\hline Target & $\begin{array}{l}\text { Masyarakat dan ibuk-ibuk kebayanan } \\
1\end{array}$ & $\begin{array}{l}\text { Karangtaruna serta masyarakat di } \\
\text { kebayanan } 1 \text { desa Puron }\end{array}$ \\
\hline Waktu & 3-5 Februari 2017 & 12 Februari 2017 \\
\hline Penanggungjawab & Enno dan Yesi & Enno dan Yesi \\
\hline Sektor terkait & Karang taruna UGMM & Karang taruna UGMM \\
\hline Indikator & $\begin{array}{l}\text { Pembentukan bank sampah dan } \\
\text { pembentukan organisasi pengurus } \\
\text { bank sampah. }\end{array}$ & Pengumpulan sampah \\
\hline Cara Monitor & $\begin{array}{l}\text { Terbentuknya bank sampah dan } \\
\text { berjalannya }\end{array}$ & Pengumpulan setiap hari Selasa. \\
\hline \multirow[t]{3}{*}{ Estimasi Dana } & Neraca timbangan:Rp 250.000 & \\
\hline & Buku administrasi :Rp 20.000 & \\
\hline & Buku tabungan nasabah :Rp20.000 & \\
\hline
\end{tabular}

\section{Sosialisasi/ Penyuluhan}

Sosialisasi/ Penyuluhan dilakukan di pengajian ibu-ibu yang berlokasi di Masjid AL-IKHLAS mengenai pembentukan Bank Sampah "MALIMPA" (Masyarakat Peduli Sampah) yang ada di Kebayanan 1 Desa Puron. Tujuan dilakukan sosialisasi/ penyuluhan ini memberdayakan masyarakat untuk memanfaatkan sampah menjadi bernilai ekonomis sehingga tidak menumpuk dan tidak menyebabkan sumber penyakit.

\section{Pembentukan Struktur Organisasi Bank Sampah}

Pada awal rencana pembentukan Bank Sampah sasaran organisasi adalah ibu-ibu di Dusun Kebayanan 1, tetapi pada saat dilakukan observasi, pihak karang taruna menginginkan untuk diberdayakan dalam kegiatan bank sampah, sehingga organisasi bank sampah tidak melibatkan ibu-ibu Kebayanan 1 melainkan karang taruna UGMM, kemudian pada hari Minggu tanggal 5 Februari 2017 dibentuk struktur organisasi bank sampah dirumah Bapak Surat Widodo yang melibatkan anggota karang taruna UGMM Dusun Platar dan Desa Puron dengan dihadiri kurang lebih 30 orang anggota karang taruna. Acara dimulai pada pukul 20.00-22.00 WIB, dengan bermusyawarah atau bincang-bincang bersama anggota karang taruna untuk memilih struktur organisasi Bank Sampah yang diberi nama 
"MALIMPA" (Masyarakat Peduli Sampah), kemudian terbentuk struktur organisasi yang terdiri dari ketua, wakil ketua, sekretaris, dan bendahara.

$\begin{array}{ll}\text { Penasehat } & \text { : Bp. Sridadi } \\ \text { Ketua } & \text { : Muhammad Nuur Fadhil } \\ \text { Wakil ketua } & \text { : Aditya M.A } \\ \text { Sekretaris } & \text { : - Alif Nur Kholifah } \\ & \text { - Dwi Saputro } \\ \text { Bendahara } & : \text { - Afifah } \\ & \text { - Asih Handayani }\end{array}$

\section{Pendampingan}

a. Pengumpulan Sampah Tahap 1 Sebelum melakukan pengumpulan sampah di bank sampah kami melakukan sosialiasi kepada warga sekitar dengan memasuki kegiatan yang sudah ada di Desa Platar maupun Puron seperti pengajian, arisan dan Senam dengan tujuan untuk memberitahukan kepada warga bahwa di kebayanan 1 khusunya Platar sudah didirikan Bank Sampah, namun lokasi bank sampah belum tersedia secara pasti, sehingga untuk sementara menggunakan rumah kosong milik adik pak bayan di Kebayanan 1 . Pada tanggal 14 Februari 2017 untuk pertama kalinya melakukan program. Sebelum pengumpulan sampah di bank sampah dilakukan syiar di masjid Platar dan Puron yang bertujun untuk memberitahukan kepada warga bahwa telah didirikan Bank Sampah di Kebayanan 1, serta meningkatkan kesadaran warga atau masyarakat terhadap sampah anorganik dengan menjadikan sampah tersebut bernilai ekonomis yang biasanya hanya dibuang percuma. Cuaca yang kurang mendukung menjadikan warga kurang antusias untuk mengumpulkan sampah, hanya terdapat 3 warga yang mengumpulkan sampah di bank sampah, kami memisahkan serta memilah beberapa macam jenis sampah, kemudian terkumpul sampah anorganik sebanyak $6,8 \mathrm{~kg}$.

b. Pengumpulan Sampah Tahap 2

Hari berikutnya pada tanggal 15 Februari 2017 dilakukan pengumpulan sampah lagi di rumah adik pak Bayan. Dengan melakukan syiar dimasjid Platar maupun Puron. Jumlah nasabah bertambah menjadi 5 orang, sebelum melakukan penimbangan sampah dilakukan pemisahan beberapa jenis sampah. Kemudian sampah ditimbang oleh panitia, akan tetapi struktur organisasi yang sudah terbentuk dengan mengikutsertakan anggota karang taruna tidak ada yang hadir serta kurang antusias dan partisipatif untuk membantu sampah yang sudah terbentuk. Sampah pada pengumpulan hari kedua terkumpul sebanyak 21 $\mathrm{kg}$ dan program berjalan dengan lancar walaupun masyarakat belum sepenuhnya ikut serta.

\section{KESIMPULAN}

Pada awal rencana pembentukan bank sampah dalam Plan of Action (POA) sasaran organisasi adalah ibu-ibu di dusun kebayanan 1, tetapi pada saat dilakukan observasi, pihak karangtaruna menginginkan untuk diberdayakan dalam kegiatan bank sampah, sehingga organisasi bank sampah tidak melibatkan ibu-ibu Kebayanan 1 melainkan karang taruna UGMM, kemudian pada hari Minggu tanggal 5 Februari 2017 dibentuk struktur organisasi bank sampah yang melibatkan anggota karang taruna UGMM Dusun Platar dan Desa Puron, tetapi karena karangtaruna yang aktif di kebayanan 1 hanya UGMM yaitu karangtaruna dusun Platar jadi hanya karangtaruna tersebut yang ikut terlibat. Bank sampah resmi berdiri dengan nama MALIMPA (Masyarakat 
Peduli Sampah), pada Plan of Action (POA) Estimasi dana yang di rencanakan adalah 290.000 tetapi pada kenyataannya hanya menghabiskan dana 180.000. Setelah pembentukan organisasi pada tgl 14 Februari diadakan pengumpulan pertama bank sampah yang terkumpul sebanyak $6,9 \mathrm{~kg}$ dengan anggota 4 orang. Kegiatan kedua pada tanggal 15 Februari anggota bertambah 5 orang menjadi 9 orang dan total sampah yang terkumpul adalah $21 \mathrm{~kg}$.

Berdirinya bank sampah MALIMPA yang melibatkan karang taruna UGMM sebagai struktur organisasi, pada awal pelaksanaan program sampah yang terkumpul sebanyak 6,9 kg dengan anggota 4 orang. Kegiatan kedua anggota bertambah 5 orang menjadi 9 orang dan total sampah yang terkumpul adalah $21 \mathrm{~kg}$. Kendala yang sering terjadi yakni karena cuaca yang sering hujan dan kurang keaktifan dari anggota karang taruna. Diharapkan untuk seterusnya bank sampah tetap terus berjalan dengan semangat memikul tanggung jawab dan bertanggung jawab dengan tugas masing-masing struktur.

Pembuatan bank sampah yang baru didirikan dan dibentuk struktur Organisasinya oleh karangtaruna UGMM masih dinaungi oleh karangtaruna dengan latar belakang anak sekolahan. Maka dari itu untuk keberlanjutannya dibutuhkan kekompakan, kebersamaan, dan saling bekerjasama dengan masyararakat sekitar dalam sosialisasi terkait Bank Sampah maupun dalam pengelolaan Bank Sampah agar tujuan dari didirikannya Bank Sampah ini bisa tercapai. Serta menambah anggota Bank sampah agar pemasukan kas di Kabayanan 1 Desa Puron bisa meningkat.

\section{DAFTAR PUSTAKA}

Asteria, D. dan Heru Heruman, Bank Sampah Sebagai Alternatif Strategi Pengelolaan Sampah Berbasis Masyarakat di Tasikmalaya.Jurnal Manusia dan Lingkungan. Vol.23 No. 1 Maret 2016.

Depkes.2009. Visi dan misi Depkes Tahun 2010-2014. Diakses dari: www.depkes.go.id. Pada tanggal 18 Januari 2017.

Dinas Kesehatan Kabupaten Sukoharjo. 2015. Profil Kesehatan Puskesmas Kecamatan Bulu.

Kementrian Kesehatan RI. 2015. Profil Kesehatan Indonesia 2014. Jakarta: Kementrian Kesehatan RI.

Unit Pelayanan Teknis Daerah (UPTD) Persampahan Dinas Pekerjaan Umum (DPU). Sukoharjo Tahun 2016. 